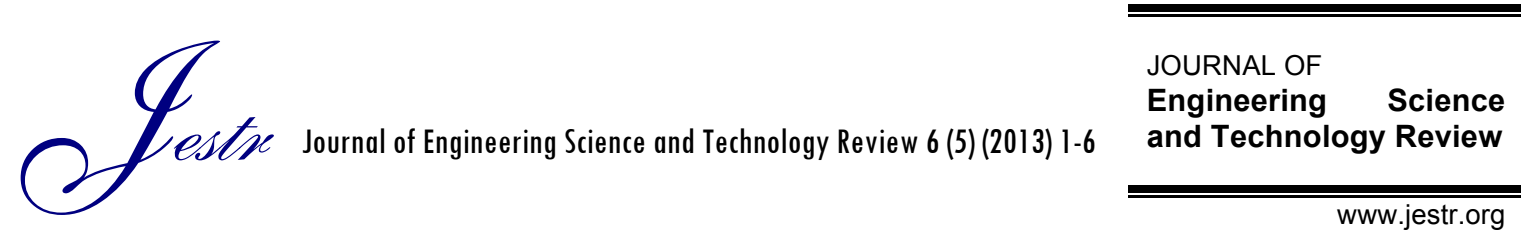

Research Article

\title{
Robustness Analysis of Sliding Mode on DC/DC for Fuel Cell Vehicle
}

\author{
Junsheng Jiao* and Xueying Cui
}

${ }^{1}$ School of Electrical Engineering, Tongling University, Tongling City, Anhui Province - China

Received 26 June 2013; Accepted 16 December 2013

\begin{abstract}
The energy conversion efficiency of fuel cell electric vehicle is high. However, the output characteristics of the current fuel cell tend to be weak and the output voltage fluctuation is apparent, so the DC/DC converter is used for voltage matching and transformation. Through the study on the characteristics of fuel cell in this paper, the main function and topology structure of the on-board DC/DC converter in fuel cell electric vehicle is introduced and the sliding mode control structure is established according to sliding mode control theory. The simulation of the sliding mode controller is performed by MATLAB. The simulation results show that, under the changes in input voltage and load, the fast response and stable output of the on-board DC/DC converter in fuel cell electric vehicle can be realized.
\end{abstract}

Keywords: Sliding Mode, Control, DC, Inverter, Fuel Cell Vehicle

\section{Introduction}

Fuel cell is represents a new technique to transform chemical energy of fuel into electrical energy directly. As the energy conversion process is not complex, so the power efficiency is higher than a general coal-fired power plant [1]. In addition, there is no combustion in the power generation process, the by-products, such as heat and water, will not produce pollution. There is no noise generated by the rotating components, the pure water can be drunk and the heat can be used for the symbiosis of vapor and electricity as if it is recycled and disposed appropriately.

With the growing problems of energy shortage and environmental pollution, there are more opportunities for the development of new energy vehicles. Fuel cell vehicle, as a kind of new energy vehicle, is getting more and more attention [2-4]. However, fuel cell vehicle must possess strong maneuverability in the adjustment for different road conditions as the traditional vehicle. The main function of the DC/DC converter as an important part of power system in fuel cell vehicles is to convert nonadjustable DC power into adjustable DC power. Then how to control each parameter of converter effectively is not related to the proper functioning of fuel cell engineer (FCE) and battery management unit (BMU), but related to the power performance, efficiency of energy utilization and reliable running of other control system of fuel cell vehicle. Fuel cell is hard to match with motor driver directly for its soft output characteristics [5-6]. The $V-I$ characteristic curve is shown in Fig. 1. At the initial period of loading in fuel cell, the voltage UFC drops faster. With the increase of load, the current increases and the voltage drops, the falling slope is much larger than ordinary cell. So the output characteristics of fuel

\footnotetext{
*E-mail address: jiaotlu@sina.com

ISSN: 1791-2377 @ 2013 Kavala Institute of Technology. All rights reserved.
}

cell are relatively soft, for a given load, the output power fluctuation can cause a decline in fuel cell efficiency.

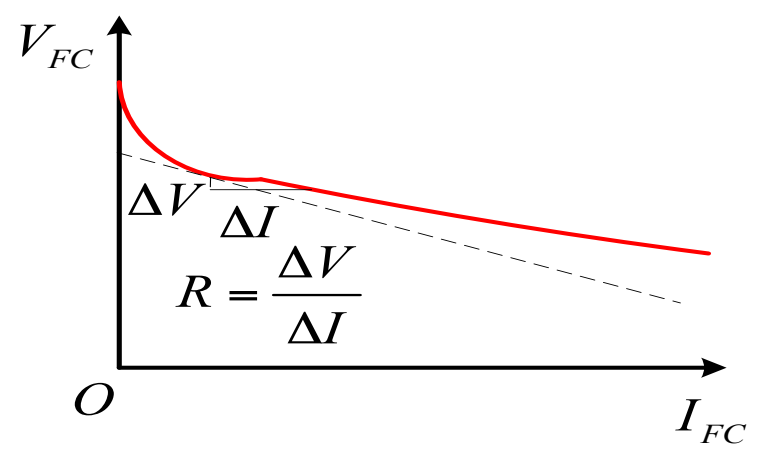

Fig. 1 The fuel cell $V-I$ characteristic curve

Therefore, DC/DC chopper is needed to add between fuel cell and DC/AC inverter [7-8], so that the fuel cell and inverter can work better. The energy transfer system structure of a typical fuel cell electric vehicle is shown in Fig. 2. The Fig. 2 shows that the energy transfer system consists of a fuel cell engine, auxiliary power system, $\mathrm{DC} / \mathrm{DC}$ chopper, $\mathrm{DC} / \mathrm{AC}$ inverter and motor.

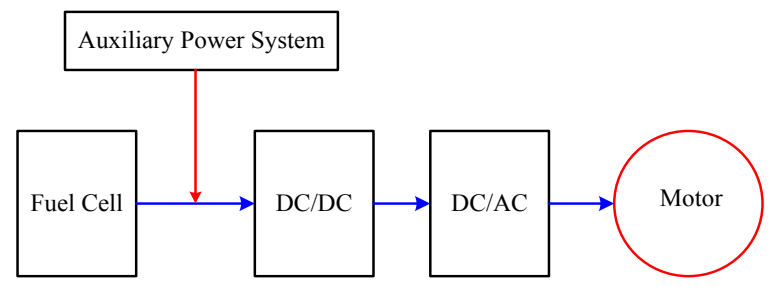

Fig. 2 The diagram of power systems for fuel cell electric vehicle 
The on-board DC/DC converter of fuel cell vehicle requires good robustness and fast dynamic response [9-12]. So a sliding mode variable structure control is proposed in this paper. The controller can adjust the normal movement characteristics, guarantee the system stability, and have a good dynamic characteristic. The effectiveness of sliding mode control is illustrated by simulation analysis.

\section{Main Circuit Structure of DC/DC Converter}

The main circuit of converter is the foundation and affects the performance of the $\mathrm{DC} / \mathrm{DC}$ converter directly. As the main circuit structure of $\mathrm{DC} / \mathrm{DC}$ converter is simple and with high work efficiency, fast response, so the vehicle economy is improved apparently. With its high working frequency and high response speed, it is easy to realize the complex and changeful characteristics of input and output to meet the requirements of different control strategies. According to the function, DC/DC converter can be divided into three kinds: boost converter, buck converter and boostbuck converter. In this paper, the boost converter is used in the fuel cell vehicle and its principle diagram is shown in Fig. 3.

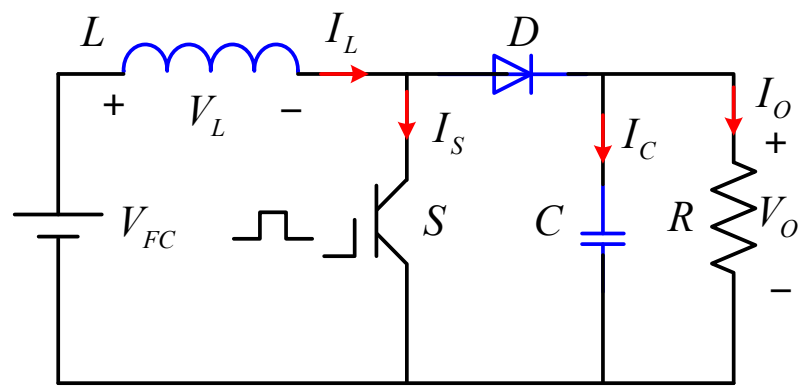

Fig. 3 Diagram of boost converter circuit

The converter waveforms in the continuous current mode (CCM) are presented in Fig. 4. When the switch $S$ is turned on, $I_{\mathrm{L}}$ traverses $L$, the current increases linearly and electric energy is stored in the form of magnetic energy in the inductor. At this moment, the capacitance $C$ discharges, $I_{\mathrm{o}}$ traverses the load and the output voltage $V_{\mathrm{o}}$ is formed at both ends, the polarity is on the negative.

When the switch $S$ is turned on, the anode of diode $D$ connects cathode, $D$ sustains the inverse voltage, so the capacitance can not discharge through the switch $S$. When the switch $S$ is cut off from conduction, the magnetic field of the inductance $L$ will change the polarity of the voltage on both ends of the coil $L$ to maintain invariability of $I_{\mathrm{L}}$. Thus the voltage $V_{\mathrm{L}}$ converted by magnetic energy connects the supply voltage $V_{\mathrm{FC}}$ in series and powers the capacitance $C$ and load above $V_{\mathrm{o}}$. When the voltage is above $V_{\mathrm{o}}$, the capacitance $C$ has charging current. When the voltage is equal to $V_{\mathrm{o}}$, the charging current is zero. When $V_{\mathrm{o}}$ has a lower trend, the capacitance discharge to the load to maintain invariability of $V_{\mathrm{o}}$. As $V_{\mathrm{L}}+V_{\mathrm{FC}}$ powers the load, $V_{\mathrm{o}}$ is higher than $V_{\mathrm{FC}}$, so a boost result is produced.

Using the Faraday law for the boost inductor, $V_{\mathrm{o}}$ can be followed as [13]:

$$
V_{O}=\frac{V_{F C}}{1-u}
$$

where $u$ is duty cycle.

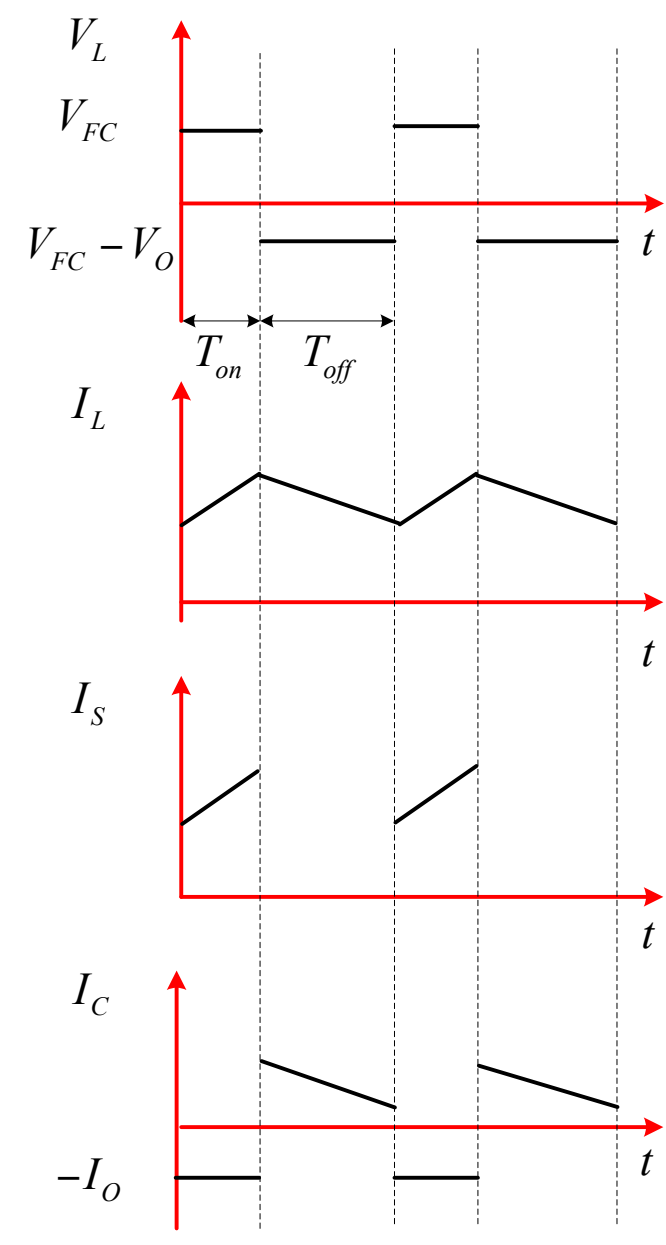

Fig. 4 Waveforms of boost converter

The boost converter operates in the continuous conduction mode for $L>L_{\mathrm{b}}$

$$
L_{b}=\frac{(1-u)^{2} u R}{2 f}
$$

\section{Sliding Mode Control Theory}

\subsection{Control Method}

Considering the DC/DC converter is single input control system, the state space equation is established as [14-15]:

$\dot{x}=f(x)+u \times g(x)$

where $x \in R^{n}, f(x) \in R^{n}, g(x) \in R^{n}, u \in[0,1], f(x)$ and $g(x)$ are smooth vector fields, $x$ represents $n$ dimensional vector constituted by system state deviation and its derivative or integral, $S(x)=K^{T} x(S \in R)$ is sliding mode surface function, $S(x)=0$ is sliding mode surface.

\subsection{The Choice of Control Law}

Generally after given sliding mode surface function, the system should reach the sliding surface fast through the control switch $u$. The control law $u$ is 0 or 1 for the characteristics of the DC/DC converter itself. That is it belongs to the limited control. There are two switch logics in DC/DC converter as follow [16-17]: 


$$
\begin{aligned}
& u=\left\{\begin{array}{ll}
0 & S<0 \\
1 & S>0
\end{array} \Rightarrow u=\frac{1+\operatorname{sgn}(S)}{2}\right. \\
& u=\left\{\begin{array}{ll}
1 & S<0 \\
0 & S>0
\end{array} \Rightarrow u=\frac{1-\operatorname{sgn}(S)}{2}\right.
\end{aligned}
$$

The equation (5) is chosen to design the sliding mode surface in this paper, which switch logic should be determined by sliding mode surface function $\mathrm{S}(\mathrm{x})$ and accessibility condition $S \dot{S}<0$.

\subsection{Lyapunov Conclusion of Sliding Mode Control}

A general conclusion drawn from DC/DC sliding surface design is given by introduction of Lyapunov derivative.

$$
L_{f} S=\nabla S f=\left[\frac{\partial S}{\partial x_{1}}, \frac{\partial S}{\partial x_{2}}, \mathrm{~L}, \frac{\partial S}{\partial x_{n}}\right] f
$$

Lyapunov derivative is the directional derivative of scalar function $S(x)$ along the vector $f(x)$ direction.

1) The existence and accessibility can be obtained by follow.

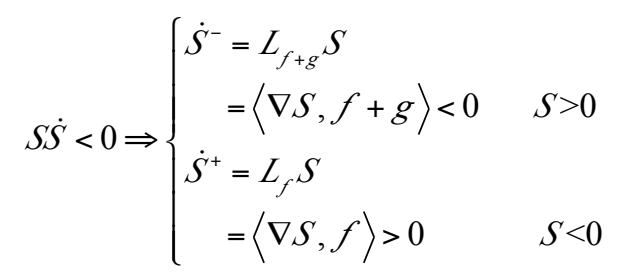

2) The necessary condition of sliding mode motion can be obtained by equation (7).

$$
L_{g} S=\langle\nabla S, g\rangle<0
$$

3) The equivalent control of sliding mode can be expressed as follow:

$$
S=0, \dot{S}=0 \Rightarrow S=0, L_{f+u_{e q} g} S=0
$$

The equivalent control can be obtained by equation (9) as follow:

$$
u_{e q}=-\frac{L_{f} S}{L_{g} S}
$$

4) The necessary and sufficient condition of sliding movement are as follow:

$$
0<u_{e q}<1
$$

\section{DC/DC Sliding Mode Control for Fuel Cell Vehicle}

As the whole working process, boost converter is the switching between two sub topologies with the characteristics of variable structure, the method of sliding mode control can be used directly for control and analysis without any simplification and approximation.

The state space average model of the boost converter is as follow:

$\left\{\begin{array}{l}\frac{d x_{1}}{d t}=\frac{1}{L}\left[V_{F C}-(1-u) x_{2}\right] \\ \frac{d x_{2}}{d t}=\frac{1}{C}\left[(1-u) x_{1}-\frac{x_{2}}{R}\right]\end{array}\right.$

where $x_{1}$ and $x_{2}$ are inductive current $I_{L}$ and $V_{O}$ of boost converter separately; $u$ represents switching function; fuel cell $V_{\mathrm{FC}}$ represents the power supply voltage of boost converter; $R$ represents load resistance.

From the control point of view, it is more difficult that the boost converter is used to control the output voltage. This is the fact that the control $u$ represents in equation (13) and (14). Such a structure suggests a strongly nonlinear system with associated difficult control design. The output voltage of the boost converter depends on control $u$ directly. Selecting the control in equation (13) and (14), the sliding mode can be enforced in $\mathrm{s}=0$ with the output voltage equal to the reference input $x_{2}^{*}$.

$u=\frac{1}{2}[1+\operatorname{sgn}(s)]$

$S=x_{2}-x_{2}^{*}$

Thus,

$$
\dot{S}=\frac{1}{2}[1-\operatorname{sgn}(S)] \frac{x_{1}}{C}-\frac{x_{2}}{R C}
$$

If $S \dot{S}<0$, after the sliding mode starting, the equation for the current $x_{1}$ can be achieved via the equivalent control means.

$[1-u]_{e q}=\frac{x_{2}^{*}}{R} \frac{1}{x_{1}}$

The equation (16) is found from $\dot{s}=0$ and substituted into the first in equation (12).

$$
\dot{x}_{1}=\frac{1}{x_{1}} \frac{V_{F C}}{L}\left[x_{1}-\frac{\left(x_{2}^{*}\right)^{2}}{V_{F C} R}\right]
$$

It is fact that the equilibrium point $x_{1}^{*}=\frac{\left(x_{2}^{*}\right)^{2}}{V_{F C} R}>0$ is unstable, therefore, the boost converter is not appropriate for the voltage control method, though it can keep the constant of output voltage.

The above state space model can be transformed into bilinear expressions of synchronous switch network for the convenience in sliding mode controller design [18].

$$
\frac{d x}{d t}=f(x)+u g(x)+h=A x+u(B x+\gamma)+\sigma(18)
$$


where $A$ and $B$ are constant square matrix representing energy vector of constant value, $f(x), g(x), h(x)$ can be expressed as the following form:

$$
\begin{aligned}
& f(x)=\sum_{j=1}^{n} a_{j}^{T} x \frac{\partial}{\partial x_{j}}, \\
& g(x)=\sum_{j=1}^{n}\left(b_{j}^{T} x+\gamma\right) \frac{\partial}{\partial x_{j}}, \\
& h(x)=\sum_{j=1}^{n} \delta_{j}^{T} x \frac{\partial}{\partial x_{j}}
\end{aligned}
$$

Bilinear expression of boost converter is as follow:

$$
\frac{d}{d t}\left[\begin{array}{l}
x_{1}^{\prime} \\
x_{2}^{\prime}
\end{array}\right]=\left\{\left[\begin{array}{cc}
0 & -e_{0} \\
e_{0} & -e_{1}
\end{array}\right]+u\left[\begin{array}{cc}
0 & e_{0} \\
-e_{0} & 0
\end{array}\right]\right\}\left[\begin{array}{l}
x_{1} \\
x_{2}
\end{array}\right]+\left[\begin{array}{l}
b \\
0
\end{array}\right]
$$

where $x_{1}^{\prime}=I_{L} \sqrt{L}, x_{2}^{\prime}=V_{O} \sqrt{C}, b=\frac{V_{F C}}{\sqrt{L}}, e_{0}=\frac{1}{\sqrt{L C}}$, $e_{1}=\frac{1}{R C}$

According to the equation (19), we can obtain:

$$
\begin{aligned}
& f(x)=\left(b-e_{0} x_{2}^{\prime}\right) \frac{\partial}{\partial x_{1}^{\prime}}+\left(e_{0} x_{1}^{\prime}-e_{1} x_{2}^{\prime}\right) \frac{\partial}{\partial x_{2}^{\prime}} \\
& g(x)=\left(e_{0} x_{2}^{\prime} \frac{\partial}{\partial x_{1}^{\prime}}-e_{0} x_{1}^{\prime}\right) \frac{\partial}{\partial x_{2}^{\prime}}
\end{aligned}
$$

Taking inductive current as feedback control quantity, the sliding surface is chosen by using the reference input $x_{1}^{*}$. $S=x_{1}^{\prime}-x_{1}^{*}=0$

The equivalent controlled quantity can be obtained as

$u_{e q}=\frac{e_{0} x_{2}^{\prime}-b}{e_{0} x_{2}^{\prime}}=1-\frac{V_{F C}}{V_{O}}$

The sliding mode area is as follow:

$$
\begin{aligned}
& R^{+}\left(x^{\prime}\right)=\left\{x^{\prime} \in R^{2}: x_{2}^{\prime}>0 ; x_{2}^{\prime}>\frac{b}{e_{0}} ; b>0\right\} \\
& R^{-}\left(x^{\prime}\right)=\left\{x^{\prime} \in R^{2}: x_{2}^{\prime}<0 ; x_{2}^{\prime}<\frac{b}{e_{0}} ; b>0\right\}
\end{aligned}
$$

The dynamic equation of sliding mode is as follow: $x_{1}^{\prime}=x_{1}^{*}, \frac{d x_{2}^{\prime}}{d t}=\frac{b x_{1}^{*}}{x^{\prime}}-e_{1} x^{\prime}$

According to the switch laws of boost circuit, the equation (27) is chosen as switching logic.

$$
u=\frac{1}{2}[1-\operatorname{sgn}(S)]
$$
$x_{2}^{\prime}$.

Therefore, the poles of dynamic system are stable about

\section{Simulation Analysis}

Fuel cell vehicle should have good mobility to cope with different condition and the output voltage fluctuation of fuel cell is apparent, the output of the converter should possess the stabilization characteristic when the input voltage and load of DC-DC switching converter are changed. The onboard DC-DC converter of fuel cell vehicle controlled by sliding mode can resist the disturbance from the input voltage and load. The converter output voltage can be stabled in the specified reference value and the converter possesses fast transient response characteristics. In order to verify the anti-interference ability of variable structure control, block diagram of simulation is illustrated in Fig. 5. The main parameters can be denoted $L=2 \mathrm{mH}, C=350 \mu \mathrm{F}$. Input voltage and output target voltage are $75 \mathrm{~V}$ and $175 \mathrm{~V}$ for simulation method separately.



Fig. 5 Block diagram of sliding mode simulation

The output characteristic analysis of fuel cell with the input voltage disturbance is illustrated in Fig. 6. When $t=0.37 \mathrm{~s}$, the input voltage is supplied with strong pulse $(75 \mathrm{~V})$ and the output voltage increased to $250 \mathrm{~V}$, the output voltage can be quickly stabilized in a reference value by sliding mode control. Switching function $S$ run into sliding mode quickly after a small amplitude oscillations near $S=0$ when the controller responded $0.05 \mathrm{~s}$ later.
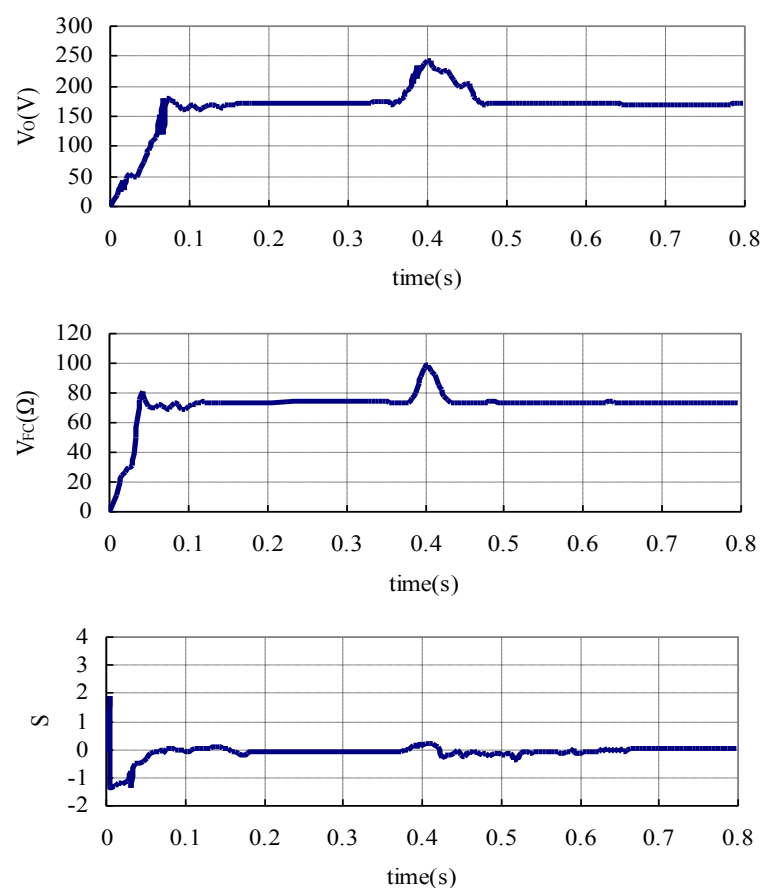

Fig. 6 Responses of system output with input change

As is illustrated in Fig. 7 at time $=0.37 \mathrm{~s}$, the output voltage of converter declines from $175 \mathrm{~V}$ to $80 \mathrm{~V}$ when the load creates a step change from $14 \Omega$ to $6 \Omega$. The response 
time maintains about $0.1 \mathrm{~s}$, so the converter has a good robustness to load disturbance and fast transient response. It can recover the stable output voltage $(175 \mathrm{~V})$ in a short time, the switch function $S$ stabilizes at $\mathrm{S}=0$. As can be seen from the above simulation test, the on-board DC/DC converter of fuel cell vehicle, which is applied to sliding mode control, can resist the disturbances from the input voltage and load. It can stabilize the output voltage in a reference value and has a fast characteristic of transient response.
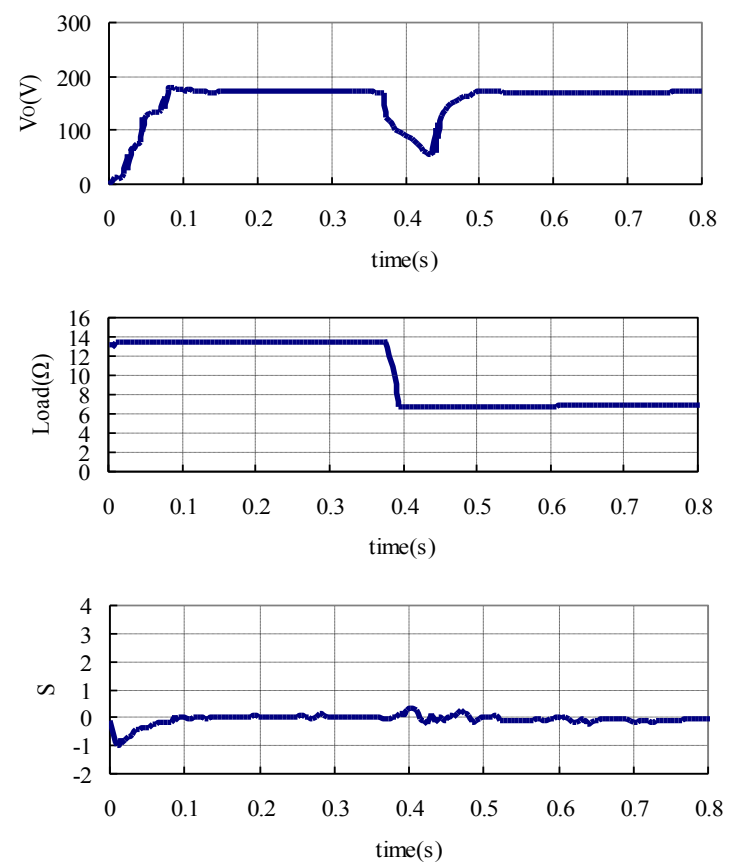

Fig. 7 Responses of system output with load change

\section{Conclusion}

In this paper, the control method of the on-board DC/DC converter in fuel cell electric vehicle has been developed to design a sliding mode algorithm. The mathematical model of DC/DC converter in fuel cell vehicle is analyzed and the simulation test of anti-interference characteristics is performed under the disturbances of input voltage and load. The convergence of the sliding mode controller is fast and effective. It shows effectiveness and robustness of the sliding mode controller and conforms to the working requirements of the on-board DC/DC converter in fuel cell vehicle.

\section{References}

1. Kirubakaran, K., Shailendra, J., Nema, R. K., "DSP-controlled power electronic interface for fuel-cell-based distributed generation", IEEE Transactions on Power Electronics, 26 (12), 2011, pp. 3853-3864.

2. Jemei, S., Hissel, D., Pera, M. C., Kauffmann, J. M., "A new modeling approach of embedded fuel-cell power Generators based on artificial neural network", IEEE Transactions on Industrial Electronics, 55 (1), 2008, pp. 437-447.

3. Fadel, A., Zhou, B., "An experimental and analytical comparison study of power management methodologies of fuel cell-battery hybrid vehicles", Journal of Power Sources, 196 (6), 2011, pp. 3271-3279.

4. Pablo, G., Torreglosa, J. P., Fernandez, L. M., Francisco, J., "Control strategies for high-power electric vehicles powered by hydrogen fuel cell, battery and supercapacitor", Expert Systems with Applications, 40 (12), 2013, pp. 4791-4804.

5. Junghwan, R., Yeongseop, P., Myoungho, S., "Electric power train modeling of a fuel cell hybrid electric vehicle and development of a power distribution algorithm based on driving mode recognition", Journal of Power Sources, 195 (17), 2010, pp. 5735-5748.

6. Phatiphat, T., Stephane, R., Bernard, D., "Energy management of fuel cell/battery/supercapacitor hybrid power source for vehicle applications", Journal of Power Sources, 193 (1), 2009, pp. 376385 .

7. Selamogullari, U. S., Torrey, D. A., Salon, S., "A systems approach for a stand-alone residential fuel cell power inverter design", IEEE Transactions on Energy Conversion, 25 (3), 2010, pp. 741-749.

8. Palma, L., Todorovic, M. H., Enjeti, P. N., "Analysis of commonmode voltage in utility-interactive fuel cell power conditioners", IEEE Transactions on Industrial Electronics, 56(1), 2009, pp. 2027.
9. Sharma, R., Hongwei, R. G., "Low cost high efficiency DC-DC converter for fuel cell powered auxiliary power unit of a heavy vehicle", IEEE Transactions on Power Electronics, 21 (3), 2006, pp. 587-591.

10. Todorovic, M. H., Palma, L., Enjeti, P. N., "Design of a wide input range DC-DC converter with a robust power control scheme suitable for fuel cell power conversion", IEEE Transactions on Industrial Electronics, 55 (3), 2008, pp. 1247-1255.

11. Specchia, S., Tillemans, F. W. A., Van. Den. Oosterkamp, P. F., Saracco, G., "Conceptual design and selection of a biodiesel fuel processor for a vehicle fuel cell auxiliary power unit", Journal of Power Sources, 145(2), 2005, pp. 683-690.

12. Rodatz, P., Paganelli, G., Sciarretta, A., Guzzella, L., "Optimal power management of an experimental fuel cell/supercapacitorpowered hybrid vehicle", Control Engineering Practice, 13 (1), 2005, pp. 41-53.

13. Rashid, M. H., Power Electronics Handbook second edition. London: Academic Press, 2007, pp. 245-250.

14. Komurcugil, H., "Non-singular terminal sliding-mode control of DC-DC buck converters", Control Engineering Practice, 21 (3), 2013, pp. 321-332.

15. Tan, S. C., Lai, Y. M., Tse, C. K., Martinez-Salamero, L., "Special family of PWM-based sliding-mode voltage controllers for basic DC-DC converters in discontinuous conduction mode", IET Electric Power Applications, 1 (1), 2007, pp. 64-74.

16. Oucheriah, S., Liping, G., "PWM-Based adaptive sliding-mode control for boost DC-DC converters", IEEE Transactions on Industrial Electronics, 60 (8), 2013, pp. 3291-3294.

17. Schirone, L., Celani, F., Macellari, M., "Discrete-time control for DC-AC converters based on sliding mode design", IET Power Electronics, 5 (6), 2012, pp. 833-840. 
Junsheng Jiao and Xueying Cui/Journal of Engineering Science and Technology Review 6 (5) (2013) 1- 6

18. Ramos, R. R., Biel, D., Fossas, E., Guinjoan, F., "A fixedfrequency quasi-sliding control algorithm: application to power inverters design by means of FPGA implementation", IEEE Transactions on Power Electronics, 18 (1), 2003, pp. 344-355. 